Article

\title{
Glutathione Restores Hg-Induced Morpho-Physiological Retardations by Inducing Phytochelatin and Oxidative Defense in Alfalfa
}

\author{
Md Atikur Rahman ${ }^{1}{ }^{(0)}$, Ahmad Humayan Kabir ${ }^{2}{ }^{(}$, Abul Mandal $^{3}{ }^{\circledR}$, Swapan Kumar Roy ${ }^{4}{ }^{(0)}$, \\ Yowook Song ${ }^{1}$, Hee Chung Ji ${ }^{1}$ and Ki-Won Lee ${ }^{1, *}$ \\ 1 Grassland and Forage Division, National Institute of Animal Science, Rural Development Administration, \\ Cheonan 31000, Korea; atikbt@korea.kr (M.A.R.); Songs0806@korea.kr (Y.S.); cornhc@korea.kr (H.C.J.) \\ 2 Molecular Plant Physiology Laboratory, Department of Botany, University of Rajshahi, \\ Rajshahi 6205, Bangladesh; ahmad.kabir@ru.ac.bd \\ 3 Systems Biology Research Center, School of Biosciences, University of Skövde, \\ 54128 Skovde, Sweden; abul.mandal@his.se \\ 4 Department of Crop Science, Chungbuk National University, Cheongju 28644, Korea; \\ swapankhulna@gmail.com \\ * Correspondence: kiwon@korea.kr; Tel.: +82-41-580-6757
}

Received: 23 September 2020; Accepted: 26 October 2020; Published: 28 October 2020

Simple Summary: An ecofriendly approach to mitigate mercury $(\mathrm{Hg})$ toxicity in alfalfa, one of the important forage crops, is highly desirable for environmental sustainability. In this study, the exogenous glutathione (GSH) substantially improved the morphological hindrance and photosynthesis inefficiency in Hg-exposed alfalfa plants. In addition, the Fe and S status of Cd-toxic alfalfa was restored due to GSH supplementation. Interestingly, GSH applied to Hg-exposed plants showed elevated $\mathrm{Hg}$ concentration in roots resulted in a substantial deposition of $\mathrm{Hg}$ in the root cell wall due to the upregulation of MsPCS1 and MsGSH1 genes in roots. It implies that GSH induces $\mathrm{PC}$ accumulation in roots enabling excess $\mathrm{Hg}$ bound to the cell wall, thereby limiting the transport of $\mathrm{Hg}$ to the aerial part of alfalfa. In silico analysis further suggests a conserved motif linked to the phytochelatin synthase domain (CL0125). In addition, GSH induced the GSH concentration and GR activity in protecting alfalfa plants from Hg-induced oxidative damage. These findings can be useful to formulate GSH-based fertilizer or to develop Hg-tolerant alfalfa plants.

Abstract: Mercury ( $\mathrm{Hg}$ ) is toxic to plants, but the effect of glutathione in $\mathrm{Hg}$ alleviation was never studied in alfalfa, an important forage crop. In this study, $\mathrm{Hg}$ toxicity showed morphological retardation, chlorophyll reduction, and PSII inefficiency, which was restored due to GSH supplementation in alfalfa plants treated with $\mathrm{Hg}$. Results showed a significant increase of $\mathrm{Hg}$, but $\mathrm{Fe}$ and $\mathrm{S}$ concentrations substantially decreased in root and shoot accompanied by the downregulation of Fe (MsIRT1) and S (MsSultr1;2 and MsSultr1;3) transporters in roots of $\mathrm{Hg}$-toxic alfalfa. However, GSH caused a significant decrease of $\mathrm{Hg}$ in the shoot, while the root $\mathrm{Hg}$ level substantially increased, accompanied by the restoration of Fe and $\mathrm{S}$ status, relative to $\mathrm{Hg}$-stressed alfalfa. The subcellular analysis showed a substantial deposition of $\mathrm{Hg}$ in the root cell wall accompanied by the increased GSH and PC and the upregulation of MsPCS1 and MsGSH1 genes in roots. It suggests the involvement of GSH in triggering PC accumulation, causing excess $\mathrm{Hg}$ bound to the cell wall of the root, thereby reducing $\mathrm{Hg}$ translocation in alfalfa. Bioinformatics analysis showed that the MsPCS1 protein demonstrated one common conserved motif linked to the phytochelatin synthase domain (CL0125) with MtPCS1 and AtMCS1 homologs. These in silico analysis further confirmed the detoxification role of MsPCS1 induced by GSH in Hg-toxic alfalfa. Additionally, GSH induces GSH and GR activity to counteract oxidative injuries provoked by $\mathrm{Hg}$-induced $\mathrm{H}_{2} \mathrm{O}_{2}$ 
and lipid peroxidation. These findings may provide valuable knowledge to popularize GSH-derived fertilizer or to develop Hg-free alfalfa or other forage plants.

Keywords: glutathione; phytochelatin; ROS scavengers; mercury detoxification; alfalfa

\section{Introduction}

Mercury $(\mathrm{Hg})$ toxicity is a severe threat to the plant, soil, and environment due to its bioaccumulation and biomagnification in different ecosystems [1]. The $\mathrm{Hg}$ is non-degradable and mobile because of the volatile potentialities of its compounds. Moreover, $\mathrm{Hg}$ can be transported within air masses over very long distances [2]. Excess $\mathrm{Hg}$ in the environment is linked to several anthropogenic activities, such as mining, sewage sludge, and application of Hg-containing fertilizer and fungicides to soils [3]. Metals exist either as separate entities or in combination with other soil components. Like other metals, $\mathrm{Hg}$ may be present in the soil in various forms, among which plants can readily accumulate mercuric ion $\left(\mathrm{Hg}^{2+}\right)$ from the soils [4]. Several studies have shown that $\mathrm{Hg}$ can be readily accumulated in higher plants [5]. Low levels of mercuric ion $\left(\mathrm{Hg}^{2+}\right)$ do not significantly affect plant growth, but the excess $\mathrm{Hg}^{2+}$ causes many physiological disorders and growth retardation [6,7]. This is undoubtedly a concern for the forage crops as toxic $\mathrm{Hg}$ may pass through the animals to the human food chain. The $\mathrm{Hg}$ can also adversely affect stomatal movement, water flow, mitochondrial activity, and photosynthesis in plants [8].

To cope with an exposure to the metal(loids) toxicity levels, plants have evolved complex defense strategies like metal exclusion, metal binding in cell wall/vacuole, chelation, and metal sequestrations, along with reactive oxygen species (ROS) homeostasis in cells [6]. Plants can accelerate some low molecular weight thiols like glutathione (GSH) and cysteine (Cys), which possess a high affinity to toxic metals [9]. GSH is a tri-peptide thiol ( $\gamma$-glutamate-cysteine-glycine), involved in growth and development, cellular defense, and antioxidant defense in stress-induced plants [6]. GSH is a component of reduced sulfur and a precursor of phytochelatins (PCs). In the cytosol, PCs form complexes with toxic metals, subsequently shifted metals into the vacuoles, protect cells from metal-induced toxicity [10]. Several studies documented that PC is involved in metal toxicity alleviation and metal transportation in plants $[6,11,12]$. PCs are synthesized by reduced glutathione (GSH) catalysis in the presence of the phytochelatin synthase. Phytochelatin synthase genes (PCS1 and PCS2) were found to be expressed differentially [13] and activated by different metal ions in several plants, including Arabidopsis [14], Lotus japonicas [15], and Triticum aestivum [16]. In Arabidopsis, the exogenous GSH inhibited $\mathrm{Hg}$ entry into root cells by binding to excess $\mathrm{Hg}$ [6]. In addition, GSH found to be useful for eliminating Cd [17,18] and As [19] toxicity in several plant species. However, there is no report available so far on the role of GSH in $\mathrm{Hg}$ mitigation in forage crops.

Plants exposed to metal toxicity suffer from oxidative stress due to the elevated reactive oxygen species (ROS) such as hydrogen peroxide $\left(\mathrm{H}_{2} \mathrm{O}_{2}\right)$, superoxide anion $\left(\mathrm{O}_{2}{ }^{\bullet-}\right)^{-}$, and hydroxyl radicle $(\bullet \mathrm{OH})$ in cells [20]. Oxidative stress leads to cellular injury, lipid peroxidation, and membrane deterioration in plant cells [21]. However, the induction of the antioxidant defense system is a common strategy in plants to counteract ROS. Several antioxidant enzymes such as superoxide dismutase (SOD), ascorbate peroxidase (APX), catalase (CAT), and glutathione reductase (GR) play critical roles to withstand ROS injury in metal-induced plants. However, plants are often incapable of protecting themselves from ROS damage under metal toxicity. Studies reported that GSH is involved in removing $\mathrm{H}_{2} \mathrm{O}_{2}$ through the AsA-GSH cycle under heavy metal stress in plants [22]. Furthermore, the modulation of cellular redox balance by minimizing ROS accumulation was also reported in tomato [23]. Zhou et al. [24] have shown the induction of SOD and APX in roots of alfalfa in counteracting $\mathrm{Hg}$ toxicity in alfalfa. However, the association of GSH in ROS scavenging needs to be validated in Hg-treated forage crops. 
Alfalfa (Medicago sativa L.) is an important forage legume for its values in animal feed, nitrogen-fixing ability, and biofuel potentialities [25]. Although $\mathrm{Hg}$ caused toxicity in alfalfa resulted in poor growth and development, the understanding of the mechanistic basis of $\mathrm{Hg}$-detoxification is still vague. In particular, the ecofriendly uses of GSH on $\mathrm{Hg}$ detoxification remained utterly unknown in alfalfa. Therefore, we assessed whether GSH does have a beneficial role in alleviating Hg-toxicity in alfalfa. We further investigated how GSH modulates $\mathrm{Hg}$ compartmentation and antioxidant defense in alfalfa under $\mathrm{Hg}$ stress.

\section{Materials and Methods}

\subsection{Plant Culture and Treatment}

Alfalfa (Medicago sativa L. cv. Vernal) seeds were surface sterilized using ethanol (70\%) for $2 \mathrm{~min}$ and then washed three times by deionized water. Seeds were then placed in a germination tray for $2 \mathrm{~d}$ before transferring to Hoagland nutrient solution ( $\mathrm{pH}$ 6.0) [26]. In addition to this nutrient solution, $\mathrm{Hg}$ and GSH were added for four treatments: control (without $\mathrm{Hg}$ and GSH) $+\mathrm{Hg}(40 \mu \mathrm{M}),+\mathrm{Hg}+\mathrm{GSH}$ $(40 \mu \mathrm{M} \mathrm{Hg}+50 \mu \mathrm{M} \mathrm{GSH})$, and +GSH $(50 \mu \mathrm{M} \mathrm{GSH})$ as previously described [6,24]. Nine individual replicates of plants were cultivated in a plastic container $(4 \mathrm{~L})$ for each treatment in a controlled environment with $14 \mathrm{~h}$ (light) and $10 \mathrm{~h}$ dark photoperiod $\left(550-560 \mu \mathrm{mol} \mathrm{s}{ }^{-1}\right.$ per $\left.\mu \mathrm{A}\right)$ at $25{ }^{\circ} \mathrm{C}$. The nutrient solution was replaced in every $4-\mathrm{d}$ interval, and the plants were cultivated for two weeks.

\subsection{Determination of Growth and Photosynthesis Parameters}

The root and shoot lengths of the harvested plants were measured using a metric scale $(\mathrm{cm})$. The root was dried with blotting paper before measuring the fresh weight (FW). The dry weight (DW) of root and shoot were recorded after dried in an oven at $80^{\circ} \mathrm{C}$ for $72 \mathrm{~h}$. The relative water content (RWC\%) was determined by using the following formula [27]: (fresh weight - dry weight)/(turgid weight - dry weight) $\times 100$.

The chlorophyll score of young trifoliate leaves was measured on the same replicate plants for each treatment before morphological measurement using SPAD (soil plant analysis development) meter (Minolta, Japan) as instructed by Yuan et al. [28]. The SPAD machine calculated the difference across the leaf between the red and the infrared (650-940 $\mathrm{nM}$ ) and provided a three-digit SPAD value [29]. Moreover, Fv/Fm (quantum efficiency of photosystem II) was measured in alfalfa young trifoliate leaves using a portable Chlorophyll Fluorometer PAM-2100 (Heinz Walz, Effeltrich, Germany). Plants were placed at dark for $1 \mathrm{~h}$ before data measurement.

\subsection{Determination of Elemental Concentration in Root, Shoot, Vacuole, and Cell Wall}

Elemental concentration in plant tissue was determined using the method described previously [30]. Root and shoot of treated plants were excised from the root-shoot transition zone; roots were washed with distilled water at least three times to remove excess $\mathrm{Hg}$ and GSH from the root surface. The root and shoot samples were separately dried in a microwave oven at $80{ }^{\circ} \mathrm{C}$ for $72 \mathrm{~h}$. Subsequently, dried samples were digested with $\mathrm{HNO}_{3} / \mathrm{HClO}_{4}(3: 1 v / v)$. Elemental $(\mathrm{Hg}, \mathrm{Fe}$, and S) concentration in digested solution was determined based on the standard known solution of that specific element by the inductively coupled plasma mass spectrometry (ICP-MS) system (Agilent 7700, ICP-MS). In order to quantify the compartmentalization of $\mathrm{Hg}$ in the root cell wall and vacuole, the centrifugation techniques were performed as previously described [31]. Briefly, fresh roots were washed with $\mathrm{dd}_{2} \mathrm{O}$ for three times. Subsequently, the samples were homogenized with a mortar and pestle (chilled) using $1 \mathrm{~mL}$ extraction buffer containing $500 \mathrm{mM}$ sucrose, $50 \mathrm{mM}$ HEPES, $5.0 \mathrm{mM}$ ascorbic acid, $1.0 \mathrm{mM}$ DTT (dithiothreitol), and 1.0\% (w/v) PVP (polyvinylpyrrolidone). The homogenate was sieved using a nylon cloth $(10 \mu \mathrm{m})$, and the residue on the nylon cloth was washed twice with the same homogenization buffer $(1 \mathrm{~mL})$ and considered as the cell wall fraction. The first filtrate was centrifuged for $10 \mathrm{~min}$ at $4000 \mathrm{rpm}$, and the precipitate (pellet) was defined as the fraction of the vacuole. The pellet was 
dried in a micro-oven at $80^{\circ} \mathrm{C}$. Finally, the $\mathrm{Hg}$ concentration of $\mathrm{Hg}$ in the cell wall and vacuole were determined using the ICP-MS approach.

\subsection{Measurement of $\mathrm{MDA}$ and $\mathrm{H}_{2} \mathrm{O}_{2}$ Levels}

The level of lipid peroxidation was measured based on the accumulation of malondialdehyde (MDA) levels in plant samples. The MDA level in fresh samples was determined according to the method described previously [32]. Of fresh tissue $100 \mathrm{mg}$ was homogenized in $5 \mathrm{~mL} 0.1 \%(w / v)$ trichloroacetic acid (TCA). The homogenate was centrifuged at 13,000 rpm for $15 \mathrm{~min}, 0.7 \mathrm{~mL}$ of supernatant was placed in a new tube wherein $0.7 \mathrm{~mL}$ TCA $20 \%$ containing $0.5 \%(w / v)$ TCA was added. The mixture was incubated at $95^{\circ} \mathrm{C}$ for $30 \mathrm{~min}$ and then kept the tubes on ice for $3 \mathrm{~min}$. The mixture was centrifuged at 13,000 rpm for $15 \mathrm{~min}$, and the absorbance of the supernatant was read at 532 and $600 \mathrm{~nm}$. The subtracted absorbance and a molar extinction coefficient of $155 \mathrm{mM}^{-1} \mathrm{~cm}^{-1}$ were used to determine the MDA concentration. The MDA concentration was calculated as $\mathrm{nmol} \mathrm{g}^{-1}$ fresh weight (FW). $\mathrm{H}_{2} \mathrm{O}_{2}$ level in the alfalfa sample was determined as described earlier [33]. The absorbance of the supernatant was read at $410 \mathrm{~nm}$. Finally, the $\mathrm{H}_{2} \mathrm{O}_{2}$ level was calculated with the extinction coefficient $0.28 \mu \mathrm{mol}^{-1} \mathrm{~cm}^{-1}$.

\subsection{RNA Isolation, cDNA Synthesis, and Gene Expression Analysis by qRT-PCR}

Total RNA was isolated from the control and treated alfalfa samples using RNeasy ${ }^{\circledR}$ plant mini kit (QIAGEN, Hilden, Germany). Shortly, 0.1g of tissue sample was homogenized with RNA extraction buffer containing $2 \mathrm{M}$ dithiothreitol (DTT) followed by centrifugation ( $\geq 12,000 \mathrm{rpm}$ ) for $2 \mathrm{~min}$. Total RNA was obtained from the supernatant, and RNA yield was recovered by adding RNase-free water $(30-50 \mu \mathrm{L})$. RNA quantification was carried out using a microvolume UV/Vis spectrophotometer (UVIS Drop-99, Taiwan). RNA concentration of $\geq 200 \mathrm{ng} / \mu \mathrm{L}$ was selected for subsequent analysis, cDNA synthesis was carried out with $1 \mu \mathrm{g}$ of total RNA using cDNA synthesis kit (Bio-Rad, Hercules, California, CA, USA). qRT-PCR was performed by the CFX96 Real-Time system (BIORAD, Hercules, California, CA, USA) for the expression of target genes using gene-specific primers (Supplementary Table S1). The total $20 \mu \mathrm{L}$ reaction mixture consisted of $10 \mu \mathrm{L}$ of $\mathrm{iQ}^{\mathrm{TM}} \mathrm{SYBR}^{\circledR}$ Green Supermix, $2 \mu \mathrm{L}$ of template cDNA, $0.8 \mu \mathrm{L}$ of forward primer $(10 \mu \mathrm{M}), 0.8 \mu \mathrm{L}$ of reverse primer $(10 \mu \mathrm{M})$, and $6.4 \mu \mathrm{L}$ of DEPC treated $\mathrm{H}_{2} \mathrm{O}$. The PCR system was programed at $95^{\circ} \mathrm{C}$ for $30 \mathrm{~s}$, followed by 40 cycles at $95{ }^{\circ} \mathrm{C}$ for $5 \mathrm{~s}$, and $60^{\circ} \mathrm{C}$ for $30 \mathrm{~s}$. The relative gene expression was analyzed using the $\mathrm{dd}^{-\Delta \mathrm{Ct}}$ method [34], using MsActin as an internal control. In each treatment for the qRT-PCR experiment, there were three replicates per biological sample.

\subsection{In Silico Characterization of the MsPCS1 Gene}

The phylogeny of MsPCS1 was assessed and characterized in contrast to the corresponding PC gene of Medicago trunculata (MtPCS1) and Arabidopsis thaliana (AtPCS1) based on the protein sequences retrieved from NCBI databases (Supplementary Table S2). Multiple sequence alignments of these three PCS proteins were performed to identify conserved residues by using Clustal Omega. We also added the molecular function of theses based on gene ontology analysis using the InterProScan software tool (https://www.ebi.ac.uk/interpro/search/sequence-search). Furthermore, the five conserved protein motifs of the proteins were characterized by MEME Suite 5.1.1 [35]. We also searched for the motif annotation and protein domains in the Pfam database [36].

\subsection{Measurement of Antioxidant Enzymes}

Plant tissue $(100 \mathrm{mg})$ samples were homogenized with $100 \mathrm{mM}$ potassium phosphate (KP-buffer, $\mathrm{pH}$ 7.0). The homogenate was centrifuged at $13,000 \mathrm{rpm}$ for $15 \mathrm{~min}$, and the aliquots of the supernatant were used for the assaying for the activities of SOD, APX, CAT, and GR. SOD activity was measured in a reaction solution of the plant extracts $(100 \mu \mathrm{L})$ combined with $0.1 \mathrm{mM}$ EDTA, $50 \mathrm{mM} \mathrm{NaHCO}_{3}(\mathrm{pH} 9.8)$, and $0.6 \mathrm{mM}$ epinephrine [37]. After $4 \mathrm{~min}$, the confirmation of adrenochrome was recorded at $475 \mathrm{~nm}$. 
For analysis of APX, extracts was mixed with $0.1 \mathrm{mM}$ EDTA, $50 \mathrm{mM} \mathrm{KP}$-buffer (pH 7.0), $0.1 \mathrm{mM} \mathrm{H}_{2} \mathrm{O}_{2}$, $0.5 \mathrm{mM}$ ascorbic acid, and $0.1 \mathrm{~mL}$ extraction. The APX activity was calculated using the extinction coefficient of $2.8 \mathrm{mM}^{-1} \mathrm{~cm}^{-1}$ using the optical density (OD) at $290 \mathrm{~nm}$. The activity of CAT was measured using $100 \mathrm{mmol} \mathrm{KP}$-buffer ( $\mathrm{pH} 7.0), 6 \% \mathrm{H}_{2} \mathrm{O}_{2}$, and $100 \mu \mathrm{L}$ plant extract, and absorbance was read at $240 \mathrm{~nm}$ (extinction coefficient $0.036 \mathrm{mM}^{-1} \mathrm{~cm}^{-1}$ ) at the $30-60$ s intervals. Further, $100 \mu \mathrm{L}$ plant extract was mixed with $0.2 \mathrm{~mol} \mathrm{KP-buffer} \mathrm{(pH} \mathrm{7.0),} 1$ mM EDTA, 20 mM oxidized glutathione (GSSG), and $0.2 \mathrm{mM}$ NADPH for measuring the GR activity. The reaction began with GSSG and decreased in absorption at $340 \mathrm{~nm}$ in the response of NADPH oxidation. The GR activities were ascertained using the extinction coefficient $6.12 \mathrm{mM}^{-1} \mathrm{~cm}^{-1}$ [38].

\subsection{Determination of Glutathione (GSH) and Phytochelatins (PCs)}

The concentration of GSH and PC was analyzed in roots of alfalfa using Empower3 ${ }^{\mathrm{TM}}$ software (Waters Corporation, Milford, MA, USA) by high-performance liquid chromatography (HPLC) at 280 and $360 \mathrm{~nm}$ with a dual Waters 2489 detector [39,40]. We used a C18 reverse-phase column as gradient conditions using $100 \%$ acetonitrile as the mobile phase. The extracts and samples were diluted $(100 \times)$ and then filtered ( $0.22 \mu \mathrm{m}$ Minisart Syringe Filters; Finetech, Taichung, Taiwan) before injection.

\subsection{Statistical Analysis}

All experiments were repeated three times performed in a completely randomized block design. All experiments had three replicates per treatment with three biological replicates. All data related to physiological and molecular experiments were statistically analyzed using the analysis of variance (ANOVA). Duncan's multiple range test (DMRT) was additionally conducted to categorize the significant differences at $p \leq 0.05$. We used SPSS 20.0 and GraphPad Prism 8.3.0 for statistical and graphical analyses, respectively. Three independent replications were considered for the analysis.

\section{Results}

\subsection{Phenotypic and Morphological Features}

The application of $\mathrm{Hg}$ in the solution culture caused phenotypic alterations (Figure 1) and RWC\% (Figure 2a) in the leaves of alfalfa relative to the plants grown without any $\mathrm{Hg}$ or GSH. The addition of GSH along with $\mathrm{Hg}$ showed a similar phenotype and RWC $\%$ to that of plants cultivated with or without GSH (control) addition (Figure 2a). Individually, the root and shoot dry weight and their lengths significantly reduced due to $\mathrm{Hg}$ stress relative to controls. However, $\mathrm{Hg}$-toxic plants supplemented with exogenous GSH showed a significant improvement in these morphological features, similar to those cultivated solely with GSH or control conditions (Figure 2b,e).

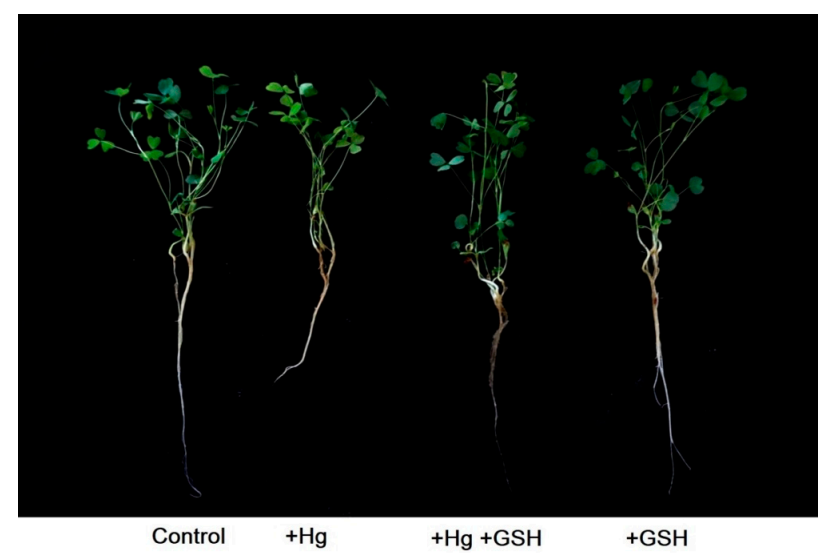

Figure 1. Alfalfa plant phenotypes. Plants cultivated in different conditions of $\mathrm{Hg}$ and GSH: $+\mathrm{Hg}(40 \mu \mathrm{M}),+\mathrm{Hg}+\mathrm{GSH}(40 \mu \mathrm{M} \mathrm{Hg}+50 \mu \mathrm{M} \mathrm{GSH})$, and $+\mathrm{GSH}(50 \mu \mathrm{M} \mathrm{GSH})$. 

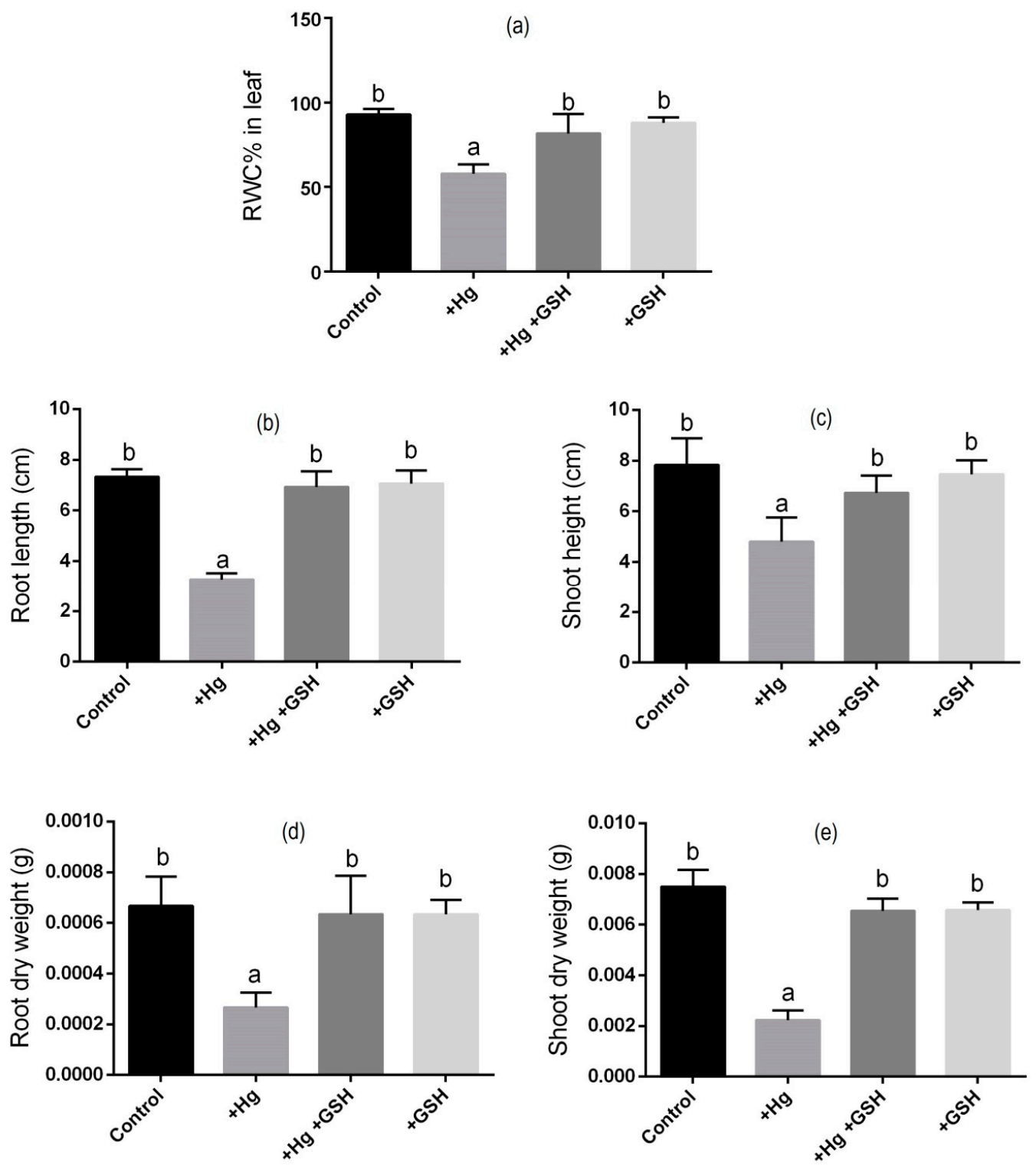

Figure 2. Changes in relative water content (RWC\%) (a), root length (b), shoot height (c), root dry weight (d), and shoot dry weight (e) of alfalfa plants cultivated in different conditions of $\mathrm{Hg}$ and GSH: +Hg $(40 \mu \mathrm{M}),+\mathrm{Hg}+\mathrm{GSH}(40 \mu \mathrm{M} \mathrm{Hg}+50 \mu \mathrm{M} \mathrm{GSH})$, and +GSH (50 $\mu \mathrm{M}$ GSH). Data represent means \pm SD of three independent biological samples. Different letters indicate a significant difference at the $p<0.05$ level.

\subsection{Characterization of Photosynthesis and Metal Elements}

The chlorophyll score and Fv/Fm significantly declined because of $\mathrm{Hg}$ stress as opposed to controls. These parameters showed a significant increase in leaves when plants were cultivated with GSH along with $\mathrm{Hg}$ compared to Hg-stressed plants (Figure 3a,b). Plant solely cultivated with GSH showed similar chlorophyll score and Fv/Fm values to that of controls or plants treated with $\mathrm{Hg}$ and GSH (Figure 3a,b). 

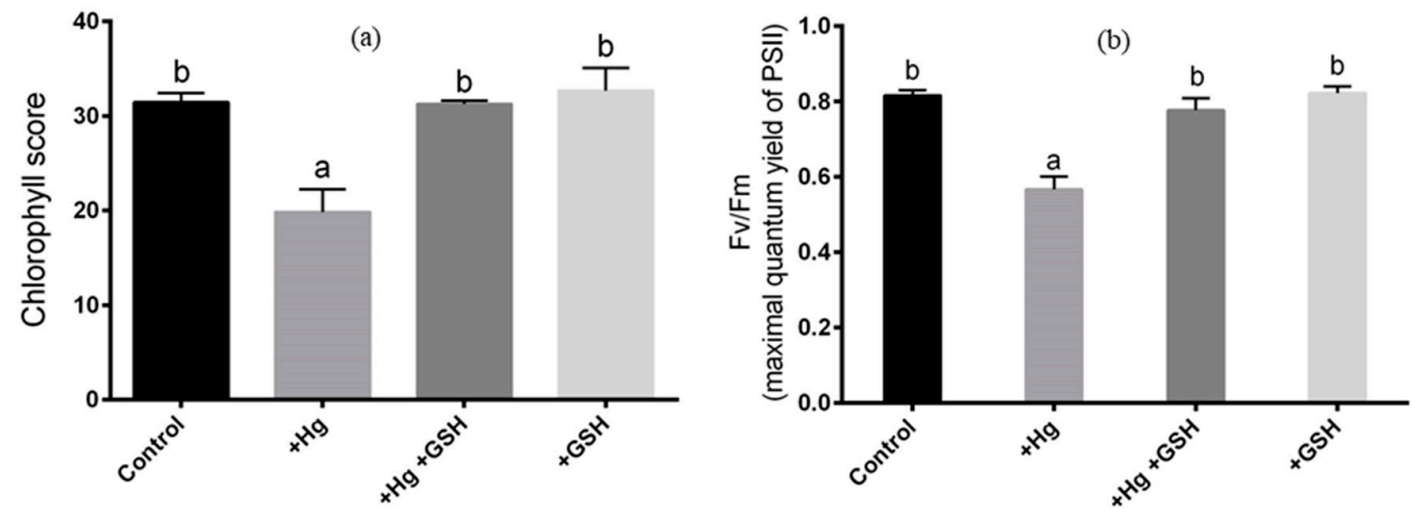

Figure 3. Changes in the chlorophyll score (a) and $\mathrm{Fv} / \mathrm{Fm}(\mathbf{b})$ values in young leaves of alfalfa cultivated in different conditions of $\mathrm{Hg}$ and GSH: $+\mathrm{Hg}(40 \mu \mathrm{M}),+\mathrm{Hg}+\mathrm{GSH}(40 \mu \mathrm{M} \mathrm{Hg}+50 \mu \mathrm{M} \mathrm{GSH})$, and $+\mathrm{GSH}$ (50 $\mu \mathrm{M}$ GSH). Data represent means \pm SD of three independent biological samples. Different letters indicate a significant difference at the $p<0.05$ level.

ICP-MS analysis showed that the root and shoot of alfalfa showed a significant increase of $\mathrm{Hg}$ due to $\mathrm{Hg}$ stress relative to non-treated controls (Figure 4a). The surplus of GSH, along with $\mathrm{Hg}$, showed a substantial rise of $\mathrm{Hg}$ in roots, while the shoot demonstrated a similar $\mathrm{Hg}$ level in contrast to Hg-toxic plants (Figure 4a). Plants solely grown with GSH showed similar Hg levels in root and shoot of alfalfa to that of control plants (Figure 4a). More precisely, the Hg toxicity showed no effect on the concentration of $\mathrm{Hg}$ in root vacuole regardless of the treatment conditions (Figure $4 \mathrm{~b}$ ). In the cell wall, the $\mathrm{Hg}$ surplus showed no changes in the concentration compared to controls. However, the excess of GSH with $\mathrm{Hg}$ showed a significant accumulation of $\mathrm{Hg}$ in cell wall relative to the plants cultivated with $\mathrm{Hg}$ or GHS or control conditions (Figure 4b). ICP-MS further showed that Fe and S concentration in both root and shoot of alfalfa significantly decreased following $\mathrm{Hg}$ surplus relative to untreated controls (Figure 4c,d). The exogenous GSH, along with $\mathrm{Hg}$, caused a significant increase of Fe and $\mathrm{S}$ status in both tissues relative to Hg-toxic plants or plants cultivated solely with GSH or untreated conditions (Figure 4c,d).
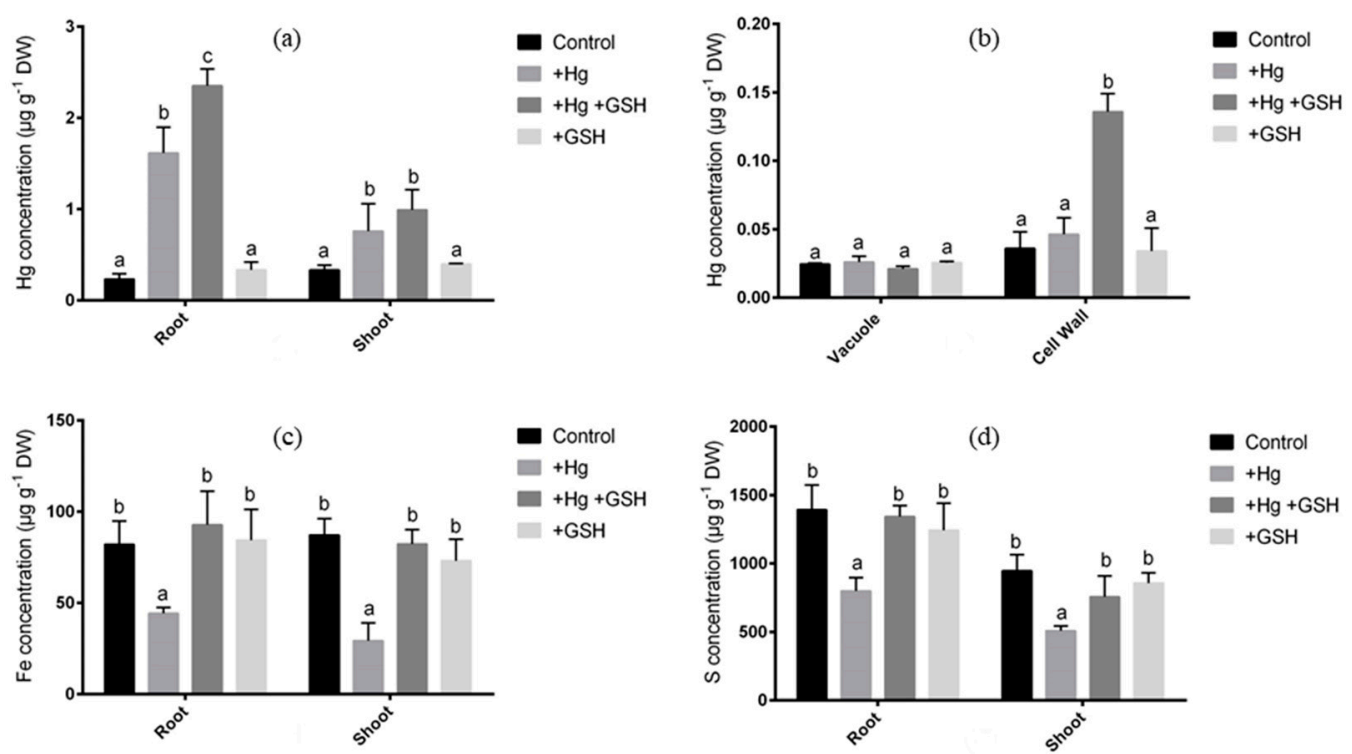

Figure 4. Elemental concentration in root shoot, vacuole, and cell wall of alfalfa. Concentration of $\mathrm{Hg}(\mathbf{a}, \mathbf{b}), \mathrm{Fe}(\mathbf{c})$ and $\mathrm{S}(\mathbf{d})$ in alfalfa cultivated in different conditions of $\mathrm{Hg}$ and GSH: $+\mathrm{Hg}(40 \mu \mathrm{M})$, $+\mathrm{Hg}+\mathrm{GSH}(40 \mu \mathrm{M} \mathrm{Hg}+50 \mu \mathrm{M} \mathrm{GSH})$, and $+\mathrm{GSH}(50 \mu \mathrm{M} \mathrm{GSH})$. Data represent means $\pm \mathrm{SD}$ of three independent biological samples. Different letters indicate a significant difference at the $p<0.05$ level. 


\subsection{Expression of Candidate Genes in Roots}

The expression of MsIRT1, MsSultr1;2, and MsSultr1;3 showed a significant decrease in roots of alfalfa due to $\mathrm{Hg}$ toxicity relative to non-treated plants (Figure $5 \mathrm{a}-\mathrm{c}$ ). However, $\mathrm{GSH}$ added with $\mathrm{Hg}$ showed significant upregulation of these transporter genes in the root compared to Hg-toxic plants, which was similar to the plants grown with or without GSH (Figure $5 \mathrm{a}-\mathrm{c}$ ). The expression of MsPCS1 and MsGSH1 showed no changes following Hg supplementation as opposed to controls (Figure $5 \mathrm{~d}$,e). However, the expression of MsPCS1 and MsGSH1 significantly induced in roots subjected to the dual supplementation of GSH and $\mathrm{Hg}$ compared to controls and plants grown under $\mathrm{Hg}$ and GSH alone (Figure 5d,e).
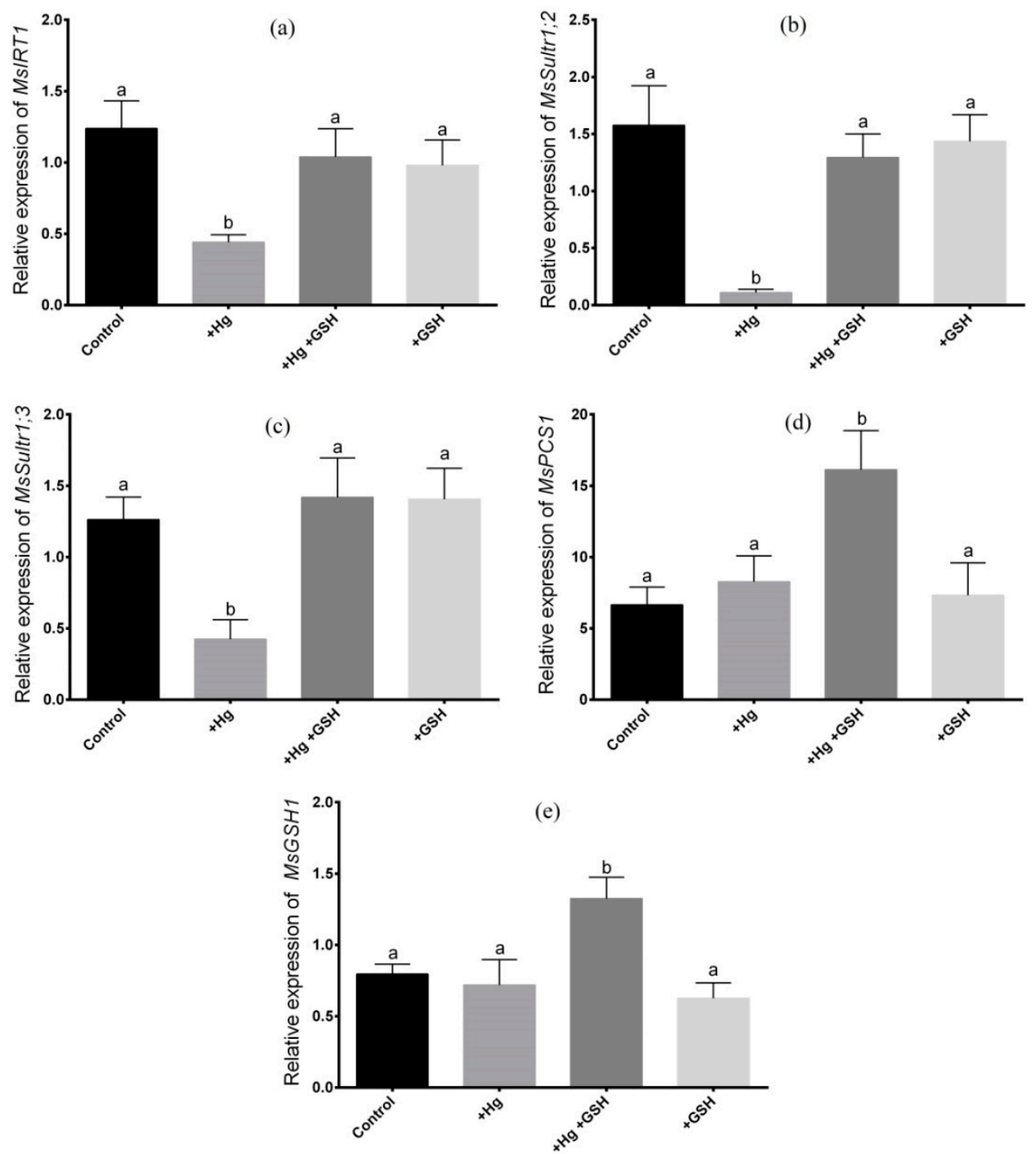

Figure 5. Expression analysis of candidate genes in roots of alfalfa. Relative expression of MsIRT1 (a), MsSultr1;2 (b), MsSultr1;3 (c), MsPCS1 (d) and MsGSH1(e) in alfalfa cultivated in different conditions of $\mathrm{Hg}$ and GSH: $+\mathrm{Hg}(40 \mu \mathrm{M}),+\mathrm{Hg}+\mathrm{GSH}(40 \mu \mathrm{M} \mathrm{Hg}+50 \mu \mathrm{MGSH})$, and +GSH (50 $\mu \mathrm{MGSH})$. Data represent means \pm SD of three independent biological samples. Different letters indicate a significant difference at the $p<0.05$ level.

\subsection{In Silico Characterization of the MsPCS1 Gene}

MSA showed similarities in the MsPCS1 protein sequence with MtPCS1 and AtPCS1 in 60-119 regions of the protein (Figure 6a). The motif search was performed using the MEME tool that showed one common motif (QNGTMEGFFRLISYFQTQSEPAFCGLASLSVVLNALAIDPGRKWKGPWRW) 
related to the phytochelatin synthase domain (CL0125) according to the database search (https: //myhits.sib.swiss/cgi-bin/motif_scan; Figure 6b).

CLUSTAL O(1.2.4) multiple sequence alignment

(a)

\begin{tabular}{|c|c|c|}
\hline MtPCS1 & MAAMAGLYRRLLPSPPSVDFASSHGKQLFFEGIQNGTMEGFYRLVSYFQTQSEPAFCGLA & 60 \\
\hline MsPCS1 & ---SSLYRRTLP-PPSIEFASPEGKKIFTEALQNGTMNGFFKLISYYQTQSDPAFCGLA & 55 \\
\hline AtPCS1 & 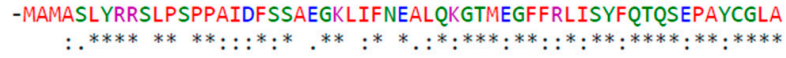 & 59 \\
\hline MtPCS1 & SLSMVLNALAIDPGRKWKGPWRWFDESMLDCCEPLEMVKSRGISFGKLVCLAHCAGAKVD & 120 \\
\hline MsPCS1 & TLSVVLNALAIDPGRKWKGPWRWW & 78 \\
\hline AtPCS1 & $\begin{array}{l}\text { SLSVVLNALSIDPGRKWKGPWRWFDESMLDCCEPLEVVKEKGISFGKVVCLAHCSGAKVE } \\
:^{* *}: * * * * *: * * * * * * * * * * * *\end{array}$ & 119 \\
\hline MtPCS1 & AFHASQSSIHDFRKYVLKCSTSDDCHVISSYHRAALKQTGNGHFSPIGGYHAGKDMALIL & 180 \\
\hline MsPCS1 & 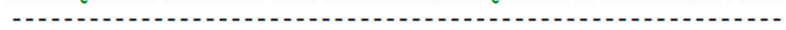 & 78 \\
\hline AtPCS1 & AFRTSQSTIDDFRKFVVKCTSSENCHMISTYHRGVFKQTGTGHFSPIGGYNAERDMALIL & 179 \\
\hline MtPCS1 & DVARFKYPPHWVPLTLLWEGMNYIDESTGQSRGFMLISRPHREPGMLYTLSCKHESWNSI & 240 \\
\hline MsPCS1 & 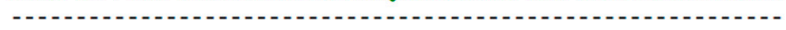 & 78 \\
\hline AtPCS1 & DVARFKYPPHWVPLKLLWEAMDSIDQSTGKRRGFMLISRPHREPGLLYTLSCKDESWIEI & 239 \\
\hline MtPCS1 & AKFLMDDVPFLLKSEDVKDIHKVLSVIFTSLPSNFEEFIKWVAEIRRREDGDSSLSAEEK & 300 \\
\hline MsPCS1 & 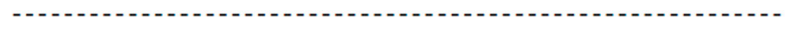 & 78 \\
\hline AtPCS1 & AKYLKEDVPRLVSSQHVDSVEKIISVVFKSLPSNFNQF IRWVAEIRITEDSNQNLSAEEK & 299 \\
\hline MtPCS1 & TRLAVKEEVLGQVQETRLFKHVSSFLSSSCGRQKLTSGDGDTLPAIAASVCCQGAEILDG & 360 \\
\hline MsPCS1 & & 78 \\
\hline AtPCS1 & SRLKLKQLVLKEVHETELFKHINKFLSTV- - - - GYEDSLTYAAAKACCQGAEILSG & 351 \\
\hline MtPCS1 & KLSSSAAYCCPETCTKCWNAEDDKSITMVSGTVVNGNTEQGVDVLIPSSSGKLCCTCSSK & 420 \\
\hline MsPCS1 & - & 78 \\
\hline AtPCS1 & SP--SKEFCCRETCVKCIKGPDDSEGTVVTGVVVRDGNEQKVDLLVPSTQTE--CECGPE & 407 \\
\hline MtPCS1 & KNIRMHPASTDVLTVLILSLPSTTWAGITDNQLLAEIHDLVSTENLSTLLQEEVLHLRRQ & 480 \\
\hline MsPCS1 & 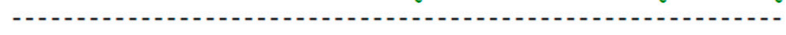 & 78 \\
\hline AtPCS1 & ---ATYPAGNDVFTALLLALPPQTWSGIKDQALMHEMKQLISMASLPTLLQEEVLHLRRQ & 464 \\
\hline MtPCS1 & LHILKRCQEGKVDEDLGAPSS & \\
\hline MsPCS1 & 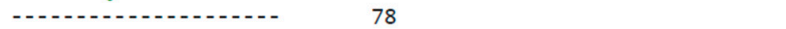 & \\
\hline AtPCS1 & LQLLKRCQENKEEDDLAAPAY & \\
\hline
\end{tabular}

(b)
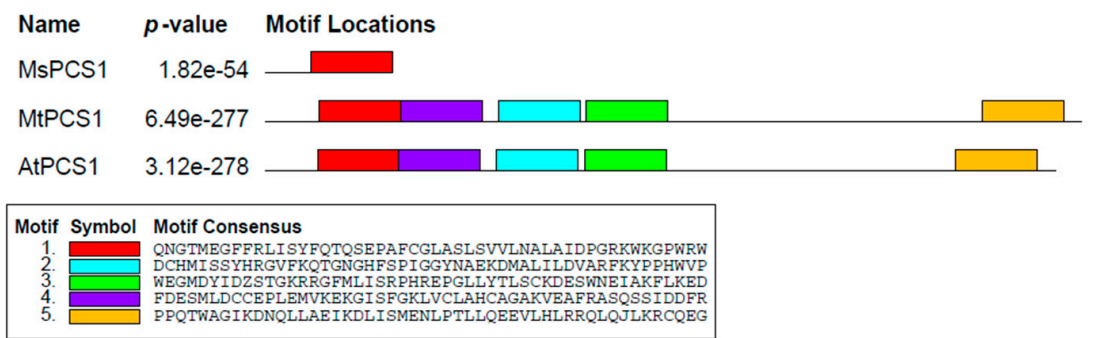

Figure 6. In silico characterization of the MsPCS1 protein in different bioinformatics platforms. Multiple sequence alignment (a) and the motif locations related to the phytochelatin synthase domains (b).

\subsection{Changes in Reactive Oxygen Species and Antioxidant Enzymes}

In this study, alfalfa plants showed no significant effect of $\mathrm{H}_{2} \mathrm{O}_{2}$ and lipid peroxidase activity in roots in the absence or presence of $\mathrm{Hg}$ and GSH (Figure 7a,b). However, the $\mathrm{H}_{2} \mathrm{O}_{2}$ and lipid peroxidase activity significantly increased in the shoot due to $\mathrm{Hg}$ surplus relative to controls. The GSH simultaneously applied with $\mathrm{Hg}$ showed a significant reduction in these ROS parameters in the shoot relative to Hg-toxic plants. Further, plants solely cultivated with GSH showed similar $\mathrm{H}_{2} \mathrm{O}_{2}$, and lipid 
peroxidase activity in the shoot to that of controls, and plants are grown in the dual application of $\mathrm{Hg}$ and GSH (Figure 7a,b). The enzymatic analysis showed no significant variations in SOD, CAT, and APX activity in either root or shoot of alfalfa in different growth conditions of $\mathrm{Hg}$ and GSH (Figure 7c-e). The GR activity only shows a significant increase in roots when plants were cultivated with GSH along with $\mathrm{Hg}$ relative to the controls and plants treated with either $\mathrm{Hg}$ or GSH alone (Figure 7f). However, the shoot GR activity did not demonstrate any changes regardless of the treatments (Figure 7f).
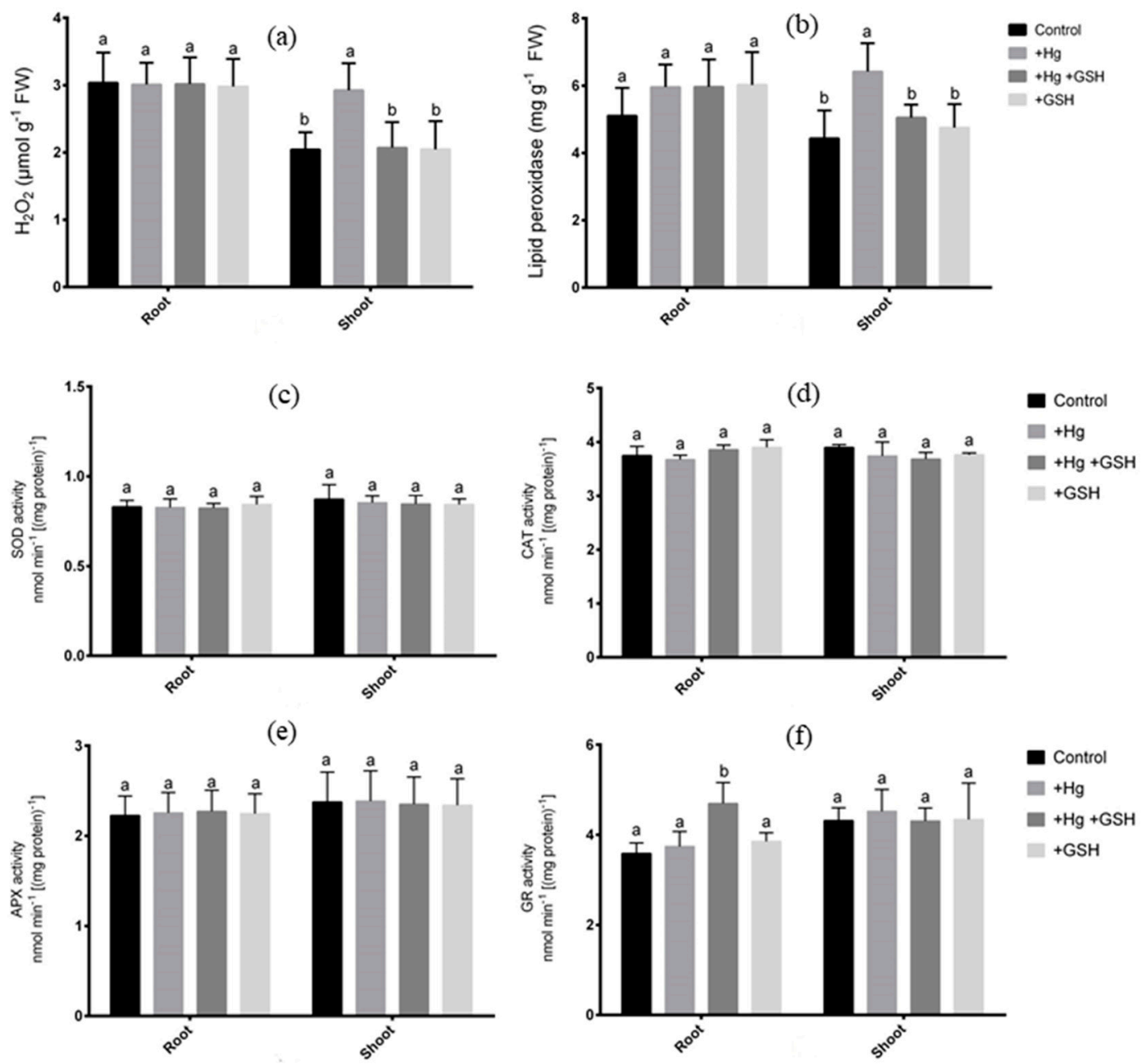

Figure 7. Changes in different ROS indicators and antioxidant enzymes in root and shoot of alfalfa. Response of $\mathrm{H}_{2} \mathrm{O}_{2}(\mathbf{a})$, lipid peroxidation (b), SOD (c), CAT (d), APX (e) and GR (f) in alfalfa cultivated in different conditions of $\mathrm{Hg}$ and GSH: $+\mathrm{Hg}(40 \mu \mathrm{M}),+\mathrm{Hg}+\mathrm{GSH}(40 \mu \mathrm{M} \mathrm{Hg}+50 \mu \mathrm{M} \mathrm{GSH})$, and $+\mathrm{GSH}$ $(50 \mu \mathrm{M}$ GSH). Data represent means \pm SD of three independent biological samples. Different letters indicate a significant difference at the $p<0.05$ level.

\subsection{Changes in Phytochelatin and Glutathione}

Although PC and GSH showed no changes due to Hg stress in roots, the addition of GSH along with $\mathrm{Hg}$ caused a significant increase of PC and GSH concentration in roots in contrast to Hg-toxic plants (Figure 8a,b). Plants cultivated solely with GSH showed similar PC and GSH to that of controls and Hg-toxic plants. The alfalfa shoot showed no significant changes in PC and GSH concentration in the absence or presence of $\mathrm{Hg}$ or GSH (Figure 8a,b). 

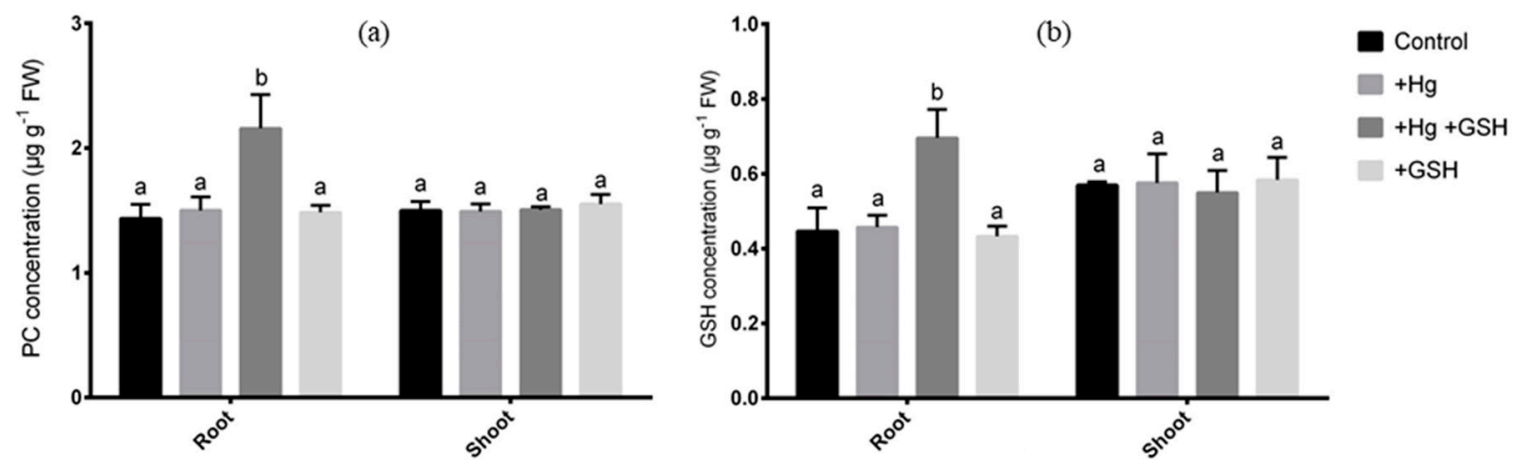

Figure 8. Changes in phytochelatin (PC) and glutathione (GSH) in alfalfa. Concentration of PC (a) and GSH (b) in the root and shoot of alfalfa cultivated in different conditions of $\mathrm{Hg}$ and GSH: $+\mathrm{Hg}(40 \mu \mathrm{M})$, $+\mathrm{Hg}+\mathrm{GSH}(40 \mu \mathrm{M} \mathrm{Hg}+50 \mu \mathrm{M}$ GSH $)$, and $+\mathrm{GSH}(50 \mu \mathrm{M}$ GSH$)$. Data represent means $\pm \mathrm{SD}$ of three independent biological samples. Different letters indicate a significant difference at the $p<0.05$ level.

\section{Discussion}

Although heavy metals are known to cause growth and metabolic disturbance of plants [6,41], the effect of GSH in Hg detoxification was not yet studied in alfalfa. Along with the stress responses, the sustainable approaches to limit $\mathrm{Hg}$ toxicity are highly desirable to ensure plant growth and maintain the natural ecosystem. In this study, GSH exogenously applied to Hg-stressed alfalfa showed dramatic improvement in the morphological and physiological, and cellular status of alfalfa. We further elucidated how GSH activated the detoxification mechanisms of $\mathrm{Hg}$ in alfalfa.

\subsection{Improvement in Morphological and Physiological Features}

The $\mathrm{Hg}$ is known to cause excess ROS, photosynthesis disturbance, and nutrient imbalance in plants $[6,42,43]$. In addition, the reduction of plant biomass is an essential indicator of metal-toxic plants. In this study, this was also noticed in alfalfa plants severely affected by $\mathrm{Hg}$ stress leading to growth reduction. Similar morphological retardation was also observed in Pteris vittata and Nephrolepis exaltata due to Hg toxicity [44]. However, we found substantial improvement in root and shoot features treated with GSH in Hg-stressed alfalfa. The morphological recovery is in agreement with the improved RWC in the leaf following GSH addition in the presence of $\mathrm{Hg}$. The change in RWC\% is considered to be associated with phytotoxicity in plants [45]. Collectively, this confirms that GSH is a beneficial element in restoring cellular and morphological damages in alfalfa plants subjected to $\mathrm{Hg}$ stress.

Phytotoxicity in leaves influences photosynthesis by disturbing both light and dark reactions of photosynthesis [43]. In this study, photosynthetic efficiency was justified by measuring chlorophyll score and Fv/Fm in the presence of $\mathrm{Hg}$ and GSH in alfalfa. Moreover, PSII photosynthesis is the primary target for metal toxicity [46]. In this study, chlorophyll synthesis and PSII efficiency showed a close relationship with or without $\mathrm{Hg}$ and GSH. The decline in chlorophyll score, along with PSII efficiency, indicates that alfalfa plants were unable to regulate PSII mechanisms under $\mathrm{Hg}$ stress. Interestingly, these photosynthesis parameters were fully restored due to GSH, suggesting that GSH facilitates the trapped light in photosynthesis and maintains the PSII activity in response to $\mathrm{Hg}$ stress in alfalfa. The Fv/Fm is widely considered as the stress indicator representing PSII photochemistry [47].

Heavy metals itself are toxic, but it also possesses the antagonistic effect of the uptake of other essential elements of plants. In this study, excess $\mathrm{Hg}$ showed the inhibitory effect of Fe and $\mathrm{S}$ uptake in alfalfa; this may also be correlated with the photosynthetic damages in leaves. The Fe-S cluster is crucial for the structural and physiological functionalities of mitochondria and chloroplasts [48]. The addition GSH caused substantial improvement in Fe and $S$ levels in the root and shoot along with the induction of Fe (MsIRT1) and S (MsSultr1;2 and MsSultr1;3) transporters in roots, suggesting the potential role of GSH in restoring Fe and S status in Hg-toxic plants. This might be correlated with the reduced $\mathrm{Hg}$ status, thereby arresting $\mathrm{Hg}^{\prime}$ s antagonistic effect in other elements following GSH supply 
in Hg-exposed alfalfa. Heavy metals alter nutrient absorption and water balance, thereby negatively affecting photosynthesis and development in plants [49]. This implies that the exogenous GSH not only mitigated $\mathrm{Hg}$ toxicity but also restored the $\mathrm{Fe}$ and $\mathrm{S}$ contents when alfalfa plants were grown in Hg-toxic conditions. Further, the improvement of Fe and S due to GSH following Cd stress might also be responsible for the restoration of photosynthetic activity in leaves of Hg-toxic alfalfa.

\subsection{Mechanisms of $\mathrm{Hg}$ Detoxifications}

The above-mentioned morphological and physiological improvement indicates that GSH can alleviate $\mathrm{Hg}$-induced toxicity in alfalfa. To get more insight into the mechanisms of detoxification, we performed the metal analysis of $\mathrm{Fe}$ and $\mathrm{S}$ along with $\mathrm{Hg}$ in alfalfa plants. In this study, ICP-MS results showed a significant accumulation of $\mathrm{Hg}$ in both the root and shoot of alfalfa under $\mathrm{Hg}$ stress. Interestingly, the GSH caused a considerable increase of $\mathrm{Hg}$, even higher than the Hg-toxic plants, in roots, that led to the reduced translocation of $\mathrm{Hg}$ into the aerial parts of the plants. It suggests that alfalfa roots retained the excess $\mathrm{Hg}$ limiting the detrimental $\mathrm{Hg}$ status in leaves due to GSH. Metal compartmentation is a common strategy of hyperaccumulator plants to cope with metal toxicity $[50,51]$. In this process, the subcellular partitioning of heavy metals coordinated by PC is associated with several plants $[39,52]$. However, the role of exogenous GSH underlies the detoxification and distribution of $\mathrm{Hg}$ is less explored. Cell walls are negatively charged in plants, binding to positively charged metals with the cation exchange ability [53]. The subcellular estimation of $\mathrm{Hg}$ showed that GSH-mediated excess $\mathrm{Hg}$ accumulation was deposited in the cell wall of roots rather than vacuoles in alfalfa. This led us to determine the concentration of GSH and PC, along with the expression of the respective genes in roots. Results showed a consistent increase of GSH and PC in roots of Hg-toxic alfalfa due to GSH, suggesting that PC might be linked to this cell wall-bound $\mathrm{Hg}$ in roots. Consistently, the expression of MsPCS1 and MsGSH1 significantly increased when $\mathrm{Hg}$ was present in the cultivation media.

The role of MsPCS1 proteins was further justified with two model plants by bioinformatics analysis. MSA and the phylogenetic tree showed a close relationship of the MsPCS1 gene with Medicago truncatula and Arabidopsis thaliana homologs, involved with metal binding in plants. Yadav [54], proposed that $\gamma$-glutamylcysteine $(\gamma$-EC) is exclusively synthesized in the chloroplast. Experimental evidence also reported the expression of AtPCS1 in chloroplasts [55]. However, it is highly possible that the expression and localization of a particular gene/protein largely depend on the type of magnitude of metal stress. Our wet-lab experiments showed the increased deposition of $\mathrm{Hg}$ in the cell wall. The Pfam results showed that all three PCS1 proteins have the CL0125 domain. Taken together, our findings confirm that GSH involves Hg detoxification in alfalfa plants by inducing PC synthesis that binds to $\mathrm{Hg}$ in the root cell wall resulted in decreased $\mathrm{Hg}$ accumulation in leaves to stabilize photosynthesis and cellular functions.

\subsection{Improvement of the Redox Status of the Cells}

The generation of oxidative stress causing lipid peroxidation and membrane damages is induced by $\mathrm{Hg}$ toxicity in plants [42,56]. Our studies also showed a substantial increase of $\mathrm{H}_{2} \mathrm{O}_{2}$ and lipid peroxidase in the shoot of alfalfa due to $\mathrm{Hg}$ toxicity. Although plants do have adaptive features to limit ROS production, this is not often efficient due to toxicity-induced severe cell damage, which is evident in alfalfa. Among the ROS scavengers, high capacity $\mathrm{H}_{2} \mathrm{O}_{2}$ scavengers, GSH, and GR activity were found to be induced Hg-treated alfalfa due to GSH. The participation of GSH and GR activity in $\mathrm{H}_{2} \mathrm{O}_{2}$ scavenging under heavy metal stress was previously reported [57,58]. Interestingly, Zhou et al. [24] reported the stimulation of APX and GR between control and Hg-toxic alfalfa cv. daiyi, which is contradictory to our results in alfalfa cv. Vernal. This implies that the antioxidant responses of different alfalfa cultivars in response to $\mathrm{Hg}$ toxicity vary due to different genetic makeup.

The role of exogenous GSH as a ROS scavenger during Hg stress is also supported by a marked reduction in lipid peroxidation, which is increased by Hg stress. The GSH-mediated ROS scavenging 
has been documented in various transgenic plants having higher endogenous GSH levels $[59,60]$. Previous studies also suggest that GSH rescues cell vitality and plant growth from $\mathrm{Hg}$ stress by relieving Hg-induced oxidative stress in Arabidopsis. This study further reported that GSH forms a stable complex with $\mathrm{Hg}$ and thus inhibits $\mathrm{Hg}$ entry into the Arabidopsis plant cell [6]. However, the role of GSH in Hg inhibition was not evident in alfalfa. Rather GSH may, at least partially, allow for ROS scavenging to stabilize redox status in $\mathrm{Hg}$-stressed alfalfa plants.

\section{Conclusions}

This is the first report of GSH uncovering the mechanisms of Hg-detoxification in alfalfa. GSH treated with $\mathrm{Hg}$ fully restored the morphological, cellular, and photosynthetic damages in alfalfa. These improvements were accompanied by the reduction of $\mathrm{Hg}$ in the shoot due to MsPCS1-driven binding of excess $\mathrm{Hg}$ in the root cell wall along with the restoration of $\mathrm{Fe}$ and $\mathrm{S}$ status in Hg-toxic alfalfa plants. In silico analysis showed a close relation of the MsPCS1 protein with two model plants, sharing a common conserved motif and domain linked to phytochelatin synthesis. In addition, GSH also triggers ROS scavenging through elevated GSH and GR activity in alfalfa. The results revealed that the application of GSH-derived fertilizer could potentially mitigate the toxicity $\mathrm{Hg}$ in alfalfa or other forage crops. Furthermore, these findings can be targeted in breeding or transgenic programs to develop plants tolerant to $\mathrm{Hg}$ stress.

Supplementary Materials: The following are available online at http://www.mdpi.com/2079-7737/9/11/364/s1, Table S1: List of primers used in qRT-PCR experiments. Table S2: Accession number and FASTA sequence of MsPCS1, MtPCS1 and AtPCS1 protein homologs.

Author Contributions: Conceptualization and Data curation, M.A.R. and A.H.K.; Formal analysis, A.H.K.; Funding acquisition, K.-W.L.; Investigation and Methodology, M.A.R.; Technical support, H.C.J., Y.S. and S.K.R.; Supervision, K.-W.L.; Writing—original draft, M.A.R. and A.H.K.; Writing—review and editing, A.M. and K.-W.L. All authors have read and agreed to the published version of the manuscript.

Funding: This study was funded by the Cooperative Research Program for Agriculture Science and Technology Development (Project No. PJ01193504). This work was also supported by the Postdoctoral Fellowship Program of the National Institute of Animal Science funded by RDA, Korea.

Conflicts of Interest: The authors declare no conflict of interest.

\section{References}

1. Hernández, L.E.; Sobrino-Plata, J.; Montero-Palmero, M.B.; Carrasco-Gil, S.; Flores-Cáceres, M.L.; Ortega-Villasante, C.; Escobar, C. Contribution of glutathione to the control of cellular redox homeostasis under toxic metal and metalloid stress. J. Exp. Bot. 2015, 66, 2901-2911. [CrossRef] [PubMed]

2. Pacyna, J.M. Recent advances in mercury research. Sci. Total Environ. 2020, 738, 139955. [CrossRef] [PubMed]

3. Alloway, B.J. Sources of Heavy Metals and Metalloids in Soils. In Heavy Metals in Soils: Trace Metals and Metalloids in Soils and their Bioavailability; Alloway, B.J., Ed.; Springer: Dordrecht, The Netherlands, 2013; pp. 11-50.

4. Fernández-Martínez, R.; Larios, R.; Gómez-Pinilla, I.; Gómez-Mancebo, B.; López-Andrés, S.; Loredo, J.; Ordóñez, A.; Rucandio, I. Mercury accumulation and speciation in plants and soils from abandoned cinnabar mines. Geoderma 2015, 253-254, 30-38. [CrossRef]

5. Israr, M.; Sahi, S.; Datta, R.; Sarkar, D. Bioaccumulation and physiological effects of mercury in Sesbania drummondii. Chemosphere 2006, 65, 591-598. [CrossRef] [PubMed]

6. Kim, Y.-O.; Bae, H.-J.; Cho, E.; Kang, H. Exogenous glutathione enhances mercury tolerance by inhibiting mercury entry into plant cells. Front. Plant Sci. 2017, 8, 683. [CrossRef]

7. Marques, A.P.G.C.; Rangel, A.O.S.S.; Castro, P.M.L. Remediation of heavy metal contaminated soils: Phytoremediation as a potentially promising clean-up technology. Crit. Rev. Environ. Sci. Technol. 2009, 39, 622-654. [CrossRef]

8. Zhang, W.-H.; Tyerman, S.D. Inhibition of water channels by $\mathrm{HgCl}_{2}$ in intact wheat root cells. Plant Physiol 1999, 120, 849-858. [CrossRef] [PubMed] 
9. Bricker, T.J.; Pichtel, J.; Brown, H.J.; Simmons, M. Phytoextraction of $\mathrm{Pb}$ and $\mathrm{Cd}$ from a superfund soil: Effects of amendments and croppings. J. Environ. Sci. Health A 2001, 36, 1597-1610. [CrossRef] [PubMed]

10. Salt, D.E.; Rauser, W.E. MGATP-dependent transport of phytochelatins across the tonoplast of oat roots. Plant Physiol. 1995, 107, 1293-1301. [CrossRef]

11. Mendoza-Cózatl, D.G.; Jobe, T.O.; Hauser, F.; Schroeder, J.I. Long-distance transport, vacuolar sequestration, tolerance, and transcriptional responses induced by cadmium and arsenic. Curr. Opin. Plant Biol. 2011, 14, 554-562. [CrossRef]

12. Xia, Y.; Liu, J.; Wang, Y.; Zhang, X.; Shen, Z.; Hu, Z. Ectopic expression of Vicia sativa caffeoyl-CoA O-methyltransferase ( $V s C C O A O M T)$ increases the uptake and tolerance of cadmium in Arabidopsis. Environ. Exp. Bot. 2018, 145, 47-53. [CrossRef]

13. Yamazaki, S.; Ueda, Y.; Mukai, A.; Ochiai, K.; Matoh, T. Rice phytochelatin synthases OsPCS1 and OsPCS2 make different contributions to cadmium and arsenic tolerance. Plant Direct. 2018, 2, e00034. [CrossRef]

14. Ha, S.B.; Smith, A.P.; Howden, R.; Dietrich, W.M.; Bugg, S.; O'Connell, M.J.; Goldsbrough, P.B.; Cobbett, C.S. Phytochelatin synthase genes from Arabidopsis and the yeast Schizosaccharomyces pombe. Plant Cell 1999, 11, 1153-1164. [CrossRef]

15. Ramos, J.; Clemente, M.R.; Naya, L.; Loscos, J.; Pérez-Rontomé, C.; Sato, S.; Tabata, S.; Becana, M. Phytochelatin synthases of the model legume Lotus japonicus. A small multigene family with differential response to cadmium and alternatively spliced variants. Plant Physiol. 2007, 143, 1110-1118. [CrossRef]

16. Wang, F.; Wang, Z.; Zhu, C. Heteroexpression of the wheat phytochelatin synthase gene (TaPCS1) in rice enhances cadmium sensitivity. Acta Biochim. Biophys. Sin. 2012, 44, 886-893. [CrossRef] [PubMed]

17. Nakamura, S.-i.; Suzui, N.; Nagasaka, T.; Komatsu, F.; Ishioka, N.S.; Ito-Tanabata, S.; Kawachi, N.; Rai, H.; Hattori, H.; Chino, M.; et al. Application of glutathione to roots selectively inhibits cadmium transport from roots to shoots in oilseed rape. J. Exp. Bot. 2013, 64, 1073-1081. [CrossRef] [PubMed]

18. Sun, H.-Y.; Wang, X.-Y.; Dai, H.-X.; Zhang, G.-P.; Wu, F.-B. Effect of exogenous glutathione and selenium on cadmium-induced changes in cadmium and mineral concentrations and antioxidative metabolism in maize seedlings. Asian J. Chem. 2013, 25, 2970-2976. [CrossRef]

19. Nakazawa, R.; Ikawa, M.; Yasuda, K.; Takenaga, H. Synergistic inhibition of the growth of suspension cultured tobacco cells by simultaneous treatment with cadmium and arsenic in relation to phytochelatin synthesis. Soil Sci. Plant Nutr. 2000, 46, 271-275. [CrossRef]

20. Sahu, G.K.; Upadhyay, S.; Sahoo, B.B. Mercury induced phytotoxicity and oxidative stress in wheat (Triticum aestivum L.) plants. Physiol. Mol. Biol. Plants 2012, 18, 21-31. [CrossRef]

21. Demiral, T.; Türkan, İ. Comparative lipid peroxidation, antioxidant defense systems and proline content in roots of two rice cultivars differing in salt tolerance. Environ. Exp. Bot. 2005, 53, 247-257. [CrossRef]

22. Szalai, G.; Kellős, T.; Galiba, G.; Kocsy, G. Glutathione as an Antioxidant and Regulatory Molecule in Plants Under Abiotic Stress Conditions. J. Plant. Growth Regul. 2009, 28, 66-80. [CrossRef]

23. Hasan, M.K.; Liu, C.; Wang, F.; Ahammed, G.J.; Zhou, J.; Xu, M.-X.; Yu, J.-Q.; Xia, X.-J. Glutathione-mediated regulation of nitric oxide, S-nitrosothiol and redox homeostasis confers cadmium tolerance by inducing transcription factors and stress response genes in tomato. Chemosphere 2016, 161, 536-545. [CrossRef] [PubMed]

24. Zhou, Z.S.; Huang, S.Q.; Guo, K.; Mehta, S.K.; Zhang, P.C.; Yang, Z.M. Metabolic adaptations to mercury-induced oxidative stress in roots of Medicago sativa L. J. Inorg. Biochem. 2007, 101, 1-9. [CrossRef] [PubMed]

25. Yang, J.; Teng, Y.; Wang, J.; Li, J. Vanadium Uptake by Alfalfa Grown in V-Cd-Contaminated Soil by Pot Experiment. Biol. Trace Elem. Res. 2011, 142, 787-795. [CrossRef]

26. Hoagland, D.R.; Arnon, D.I. The Water-Culture Method for Growing Plants without Soil; California Agricultural Experiment Station: Los Angeles, CA, USA, 1950; Volume 347, p. 32.

27. Pieczynski, M.; Marczewski, W.; Hennig, J.; Dolata, J.; Bielewicz, D.; Piontek, P.; Wyrzykowska, A.; Krusiewicz, D.; Strzelczyk-Zyta, D.; Konopka-Postupolska, D.; et al. Down-regulation of CBP80 gene expression as a strategy to engineer a drought-tolerant potato. Plant Biotechnol. J. 2013, 11, 459-469. [CrossRef]

28. Yuan, Z.; Cao, Q.; Zhang, K.; Ata-Ul-Karim, S.T.; Tian, Y.; Zhu, Y.; Cao, W.; Liu, X. Optimal leaf positions for SPAD meter measurement in rice. Front. Plant Sci. 2016, 7, 719. [CrossRef]

29. Uddling, J.; Gelang-Alfredsson, J.; Piikki, K.; Pleijel, H. Evaluating the relationship between leaf chlorophyll concentration and SPAD-502 chlorophyll meter readings. Photosynth. Res. 2007, 91, 37-46. [CrossRef] 
30. Rahman, M.A.; Parvin, M.; Das, U.; Ela, E.J.; Lee, S.-H.; Lee, K.-W.; Kabir, A.H. Arbuscular mycorrhizal symbiosis mitigates iron (Fe)-deficiency retardation in alfalfa (Medicago sativa L.) through the enhancement of Fe accumulation and sulfur-assisted antioxidant defense. Int. J. Mol. Sci. 2020, 21, 2219. [CrossRef]

31. Pourghasemian, N.; Landberg, T.; Ehsanzadeh, P.; Greger, M. Different response to Cd stress in domesticated and wild safflower (Carthamus spp.). Ecotoxicol. Environ. Saf. 2019, 171, 321-328. [CrossRef]

32. Peever, T.L.; Higgins, V.J. Electrolyte leakage, lipoxygenase, and lipid peroxidation induced in tomato leaf tissue by specific and nonspecific elicitors from Cladosporium fulvum. Plant Physiol. 1989, 90, 867-875. [CrossRef]

33. Rahman, M.A.; Alam, I.; Kim, Y.-G.; Ahn, N.-Y.; Heo, S.-H.; Lee, D.-G.; Liu, G.; Lee, B.-H. Screening for salt-responsive proteins in two contrasting alfalfa cultivars using a comparative proteome approach. Plant Physiol. Biochem. 2015, 89, 112-122. [CrossRef] [PubMed]

34. Livak, K.J.; Schmittgen, T.D. Analysis of relative gene expression data using real-time quantitative PCR and the $2^{-\Delta \Delta C T}$ method. Methods 2001, 25, 402-408. [CrossRef] [PubMed]

35. Timothy, B.L.; Charles, E. Fitting a mixture model by expectation maximization to discover motifs in bipolymers. Proc. Int. Conf. Intell. Syst. Mol. Biol. 1994, 2, 28-36.

36. El-Gebali, S.; Mistry, J.; Bateman, A.; Eddy, S.R.; Luciani, A.; Potter, S.C.; Qureshi, M.; Richardson, L.J.; Salazar, G.A.; Smart, A.; et al. The Pfam protein families database in 2019. Nucleic Acids Res. 2019, 47, D427-D432. [CrossRef]

37. Sun, M.; Zigman, S. An improved spectrophotometric assay for superoxide dismutase based on epinephrine autoxidation. Anal. Biochem. 1978, 90, 81-89. [CrossRef]

38. Halliwell, B.; Foyer, C.H. Properties and physiological function of a glutathione reductase purified from spinach leaves by affinity chromatography. Planta 1978, 139, 9-17. [CrossRef]

39. Kabir, A.H.; Hossain, M.M.; Khatun, M.A.; Mandal, A.; Haider, S.A. Role of silicon counteracting cadmium toxicity in alfalfa (Medicago sativa L.). Front. Plant Sci. 2016, 7, 1117. [CrossRef]

40. Lindberg, S.; Landberg, T.; Greger, M. Cadmium uptake and interaction with phytochelatins in wheat protoplasts. Plant Physiol. Biochem. 2007, 45, 47-53. [CrossRef]

41. Larbi, A.; Morales, F.; Abadía, A.; Gogorcena, Y.; Lucena, J.J.; Abadía, J. Effects of Cd and Pb in sugar beet plants grown in nutrient solution: Induced Fe deficiency and growth inhibition. Funct. Plant Biol. 2002, 29, 1453-1464. [CrossRef]

42. Ortega-Villasante, C.; Hernández, L.E.; Rellán-Álvarez, R.; Del Campo, F.F.; Carpena-Ruiz, R.O. Rapid alteration of cellular redox homeostasis upon exposure to cadmium and mercury in alfalfa seedlings. New Phytol. 2007, 176, 96-107. [CrossRef]

43. Patra, M.; Bhowmik, N.; Bandopadhyay, B.; Sharma, A. Comparison of mercury, lead and arsenic with respect to genotoxic effects on plant systems and the development of genetic tolerance. Environ. Exp. Bot. 2004, 52, 199-223. [CrossRef]

44. Chen, J.; Shiyab, S.; Han, F.X.; Monts, D.L.; Waggoner, C.A.; Yang, Z.; Su, Y. Bioaccumulation and physiological effects of mercury in Pteris vittata and Nephrolepis exaltata. Ecotoxicology 2008, 18, 110. [CrossRef] [PubMed]

45. Rucińska-Sobkowiak, R. Water relations in plants subjected to heavy metal stresses. Acta Physiol. Plant. 2016, 38, 257. [CrossRef]

46. Popova, L.P.; Maslenkova, L.T.; Yordanova, R.Y.; Ivanova, A.P.; Krantev, A.P.; Szalai, G.; Janda, T. Exogenous treatment with salicylic acid attenuates cadmium toxicity in pea seedlings. Plant Physiol. Biochem. 2009, 47, 224-231. [CrossRef] [PubMed]

47. He, J.Y.; Ren, Y.F.; Zhu, C.; Yan, Y.P.; Jiang, D.A. Effect of Cd on growth, photosynthetic gas exchange, and chlorophyll fluorescence of wild and Cd-sensitive mutant rice. Photosynthetica 2008, 46, 466. [CrossRef]

48. Abdel-Ghany, S.E.; Ye, H.; Garifullina, G.F.; Zhang, L.; Pilon-Smits, E.A.H.; Pilon, M. Iron-sulfur cluster biogenesis in chloroplasts. Involvement of the scaffold protein CpIscA. Plant Physiol. 2005, 138, 161-172. [CrossRef]

49. Singh, S.; Parihar, P.; Singh, R.; Singh, V.P.; Prasad, S.M. Heavy metal tolerance in plants:role of transcriptomics, proteomics, metabolomics, and ionomics. Front. Plant Sci. 2016, 6, 1143. [CrossRef] [PubMed]

50. DalCorso, G.; Manara, A.; Furini, A. An overview of heavy metal challenge in plants: From roots to shoots. Metallomics 2013, 5, 1117-1132. [CrossRef]

51. Leitenmaier, B.; Küpper, H. Compartmentation and complexation of metals in hyperaccumulator plants. Front. Plant Sci. 2013, 4, 374. [CrossRef] 
52. Greger, M.; Kabir, A.H.; Landberg, T.; Maity, P.J.; Lindberg, S. Silicate reduces cadmium uptake into cells of wheat. Environ. Pollut. 2016, 211,90-97. [CrossRef]

53. Carrier, P.; Baryla, A.; Havaux, M. Cadmium distribution and microlocalization in oilseed rape (Brassica napus) after long-term growth on cadmium-contaminated soil. Planta 2003, 216, 939-950. [CrossRef] [PubMed]

54. Yadav, S.K. Heavy metals toxicity in plants: An overview on the role of glutathione and phytochelatins in heavy metal stress tolerance of plants. S. Afr. J. Bot. 2010, 76, 167-179. [CrossRef]

55. Picault, N.; Cazalé, A.C.; Beyly, A.; Cuiné, S.; Carrier, P.; Luu, D.T.; Forestier, C.; Peltier, G. Chloroplast targeting of phytochelatin synthase in Arabidopsis: Effects on heavy metal tolerance and accumulation. Biochimie 2006, 88, 1743-1750. [CrossRef] [PubMed]

56. Cargnelutti, D.; Tabaldi, L.A.; Spanevello, R.M.; de Oliveira Jucoski, G.; Battisti, V.; Redin, M.; Linares, C.E.B.; Dressler, V.L.; de Moraes Flores, E.M.; Nicoloso, F.T. Mercury toxicity induces oxidative stress in growing cucumber seedlings. Chemosphere 2006, 65, 999-1006. [CrossRef] [PubMed]

57. Bari, M.A.; Akther, M.S.; Reza, M.A.; Kabir, A.H. Cadmium tolerance is associated with the root-driven coordination of cadmium sequestration, iron regulation, and ROS scavenging in rice. Plant Physiol. Biochem. 2019, 136, 22-33. [CrossRef]

58. Hsu, Y.T.; Kao, C.H. Cadmium toxicity is reduced by nitric oxide in rice leaves. Plant Growth Regul. 2004, 42, 227-238. [CrossRef]

59. Jozefczak, M.; Remans, T.; Vangronsveld, J.; Cuypers, A. Glutathione is a key player in metal-induced oxidative stress defenses. Int. J. Mol. Sci. 2012, 13, 3145-3175. [CrossRef]

60. Freeman, J.L.; Persans, M.W.; Nieman, K.; Albrecht, C.; Peer, W.; Pickering, I.J.; Salt, D.E. Increased glutathione biosynthesis plays a role in nickel tolerance in thlaspi nickel hyperaccumulators. Plant Cell 2004, 16, 2176-2191. [CrossRef]

Publisher's Note: MDPI stays neutral with regard to jurisdictional claims in published maps and institutional affiliations. 